\section{Should we teach regenerative medicine during undergraduate education?}

\section{Anna Bajek, Tomasz Drewa \\ Department of Tissue Engineering, Nicolaus Copernicus, Bydgoszcz, Poland}

Regenerative medicine is a new discipline. Its rapid development is based on tissue engineering techniques (in vitro tissues construction or induction of in vivo regeneration) used for restoring and replacing damaged organs. Emerging medical technologies, like regenerative medicine, stem cell engraftment, cell tracking require appropriate teaching. ${ }^{1}$ Regenerative medicine opens new perspectives, which can change management of many diseases, but doctors must be educated in this field. Regenerative medicine probably will be a distinct medical specialization in the near future. Then the knowledge and practical skills in this field will be obligatory. Should we start to teach regenerative medicine during undergraduate medical education? It was shown that student feedback from surveys could be a resolution. Students' active participation in curriculum content development can be important part of creating medical education. ${ }^{2}$ A survey can help to find an appropriate moment for including regenerative medicine into curriculum of undergraduate education.

We wanted to assess the degree of interest of students in applying regenerative medicine in routine practice. The survey was addressed to the first year medical students of our faculty. Anonymous questionnaires were prepared.
Survey consisted of 3 closed questions: concerning the definition of regenerative medicine, tissue engineering products knowledge and interest in increase the knowledge about it during undergraduate education. The survey was printed and filled voluntary in 2011. The questionnaire could be filled only once.

Results of survey showed that medical students are really interested in regenerative medicine and tissue-engineered products. The total number of responders was 160 (the whole community of the first year). The question: Are you able to define the concept of regenerative medicine? 87 people (54.3\%) replied in the affirmative. The question: Do you know tissueengineered products? 90 (54.4\%) replied in the affirmative. The question: Would you be interested in extending your knowledge of tissue engineering and regenerative medicine? 135 students (84.4\%) replied in the affirmative.

The creation of modern and adjustable for science development curriculum is a team work of students, doctors, and university staff. Emerging medical technologies require appropriate teaching. We are obligated as a medical faculty to think about the new directions of medicine development to keep abreast of the times.

The survey results certainly indicate that there is a high interest in the practical application and increasing the knowledge of tissue engineered products among medicine students and regenerative medicine in clinical settings, as well. We should believe students and doctors, and respect their point of medical education improvement. Our Medical Faculty has introduced an obligatory subject Regenerative Medicine for students of the $5^{\text {th }}$ year. We do hope it stands test of time.
Correspondence: Tomasz Drewa, Nicolaus Copernicus University, Karlowicza 24, str. 85-092 Bydgoszcz, Poland.

Tel. +48.525853737 - Fax: +48.525853742.

E-mail: tomaszdrewa@wp.pl

Key words: regenerative medicine; curriculum;

Conflict of interests: the authors report no conflicts of interest.

Received for publication: 23 September 2011. Accepted for publication: 23 September 2011.

This work is licensed under a Creative Commons Attribution NonCommercial 3.0 License (CC BYNC 3.0).

(C) Copyright A. Bajek and T. Drewa, 2011

Licensee PAGEPress, Italy

Stem Cell Studies 2011; 1:e14

doi:10.4081/scs.2011.e14

\section{References}

1. Varga NL, Bárcena A, Fomin ME, Muench M0. Detection of human hematopoietic stem cell engraftment in the livers of adult immunodeficient mice by an optimized flow cytometric method. Stem Cell Stud 2010;1. pii: e5.

2. Peluso M, Takizawa P. Student involvement in the development of integrated curricula. Med Educ 2010;44:1120-1. 